\title{
POTENSI PENERIMAAN RETRIBUSI IZIN MENDIRIKAN BANGUNAN (IMB) DI KABUPATEN KLATEN
}

\author{
Paramita Lea Christanti ${ }^{1}$ \\ Fakultas Ekonomi Universitas Widya Dharma Klaten ${ }^{1}$ \\ leaparamita@gmail.com ${ }^{1}$
}

\begin{abstract}
ABSTRAK
Izin mendirikan bangunan (IMB) merupakan bagian penting dalam izin pemanfaatan ruang yang dapat mewujudkan tata ruang yang proporsional. IMB merupakan bagian dalam jenis retribusi daerah yang akan menambah jumlah penerimaan pemerintah daerah yang merupakan bagian dari Pendapatan Asli Daerah. Pendapatan Asli daerah (PAD) bisa menggambarkan kemandirian sebuah daerah dalam mengelola dan mencukupi kebutuhan pembelanjaan daerah tersebut. Penelitian ini berfokus pada kontribusi Retribusi IMB terhadap retribusi daerah dan Potensi Penerimaan Retribusi IMB Tahun 2020-2022. Motode Penelitian menggunakan Deskriptif Kualitatif. Teknik pengumpulan data menggunakan dokumentasi yang berupa dokumen Anggaran dan Realisasi Pendapatan daerah Kabupaten Klaten Tahun 2014-2019. Kesimpulan dari penelitian ini adalah (1) Tingkat Kontribusi Retribusi IMB terhadap Retribusi daerah kabupaten Klaten dalam kategori kurang dan sangat kurang, (2) Potensi Penerimaan retribusi IMB peramalan tahun 2020-2022 justru mengalami penurunan di 2020 dan meningkat perlahan di tahun 2021 dan 2022.
\end{abstract}

Kata Kunci : Izin Mendirikan Bangunan (IMB), Retribusi Daerah, Kontribusi, Potensi Penerimaan, Pendapatan Asli Daerah

\section{Abstract}

Building construction permit (IMB) is an important part of a space utilization permit that can create a proportional spatial layout. IMB is part of the type of regional retribution that will increase the amount of local government revenue which is part of the Regional Original Revenue. Original regional income (PAD) can describe the independence of a region in managing and meeting the expenditure needs of the area. This research focuses on the contribution of IMB Levies to Regional Levies and the Potential for IMB Retribution for 2020-2022. The research method used was descriptive qualitative. The data collection technique uses documentation in the form of a budget document and the realization of regional income in Klaten Regency 20142019. The conclusions of this study are (1) the level of IMB levies contribution to the Klaten regency regional levies is in the category of less and very less, (2) the potential for receiving IMB levies forecasting 202O-2022 has actually decreased in 2020 and increased slowly in 2021 and 2022.

Keywords: Building Construction Permit (IMB), Regional Retribution, Contribution, Potential Revenue, Regional Original Income

Diterima: 20 Februari 2021; Direvisi: 12 April 2021; Diterbitkan: 20 April 2021 


\section{PENDAHULUAN}

Pemerintahan daerah akan berjalan dengan baik dengan dukungan pendanaan yang baik. Sumber penerimaan daerah terdiri dari beberapa komponen mulai dari Pendapatan Asli daerah (yang terdiri dari pajak dan retribusi daerah, hasil pengelolaan kekayaan daerah, lain-lain PAD yang sah), dana Perimbangan, Pendapatan daerah yang sah. Pendapatan Asli Daerah menjadi sumber pendanaan daerah yang paling bisa diusahan oleh pemerintah daerah.

Retribusi daerah menjadi komponen Pendapatan Asli Daerah yang bisa dijadikan sumber pendanaan. Jenis dari retribusi daerah yang diperkenankan dipungut oleh pemerintan daerah ada beberapa yaitu retribusi jasa umum, retribusi jasa usaha dan perizinan tertentu. Dalam penelitian ini akan di kupas lebih dalam tentang retibusi perizinan tertentu yaitu Izin mendirikan Bangunan.

Mewujudkan tata ruang yang sesuai peruntukannya menurut Peraturan Daerah Kabupaten Klaten No 11 Tahun 2011 Tentang rencana Tata Ruang Wilayah Kabupaten Klaten Tahun 2011-2031 diperlukan adanya izin pemanfaatan ruang yang berupa : (a) izin prinsip, (b) izin lokasi, (c) izin penggunaan pemanfaatan tanah, (d) izin mendirikan bangunan, dan (e) izin lain berdasarkan peraturan perundang-undangan. Izin mendirikan bangunan (IMB) merupakan bagian penting dalam izin pemanfaatan ruang yang dapat mewujudkan tata ruang yang proporsional. IMB merupakan bagian dalam jenis retribusi daerah yang akan menambah jumlah penerimaan pemerintah daerah yang merupakan bagian dari Pendapatan Asli Daerah. Pendapatan Asli daerah (PAD) bisa menggambarkan kemandirian sebuah daerah dalam mengelola dan mencukupi kebutuhan pembelanjaan daerah tersebut. Maka mengingat IMB cukup penting dalam penerimaan daerah makan penelitian ini akan mengankat tema tentang "Potensi Penerimaan retribusi Izin Mendirikan Bangunan (IMB) di Kabupaten Klaten”

\section{LANDASAN TEORI}

\section{Retribusi daerah}

Menurut Undang-Undang No 28 Tahun 2009 Retribusi Daerah merupakan pungutan Daerah sebagai pembayaran atas jasa atau pemberian izin tertentu yang khusus disediakan dan/atau diberikan oleh Pemerintah Daerah untuk kepentingan orang pribadi atau badan. Yang menjadi objek retribusi daerah yaitu : (1) Jasa Umum, (2) Jasa Usaha, dan (3) Perizinan Tertentu.

1. Objek Retribusi Jasa Umum merupakan pelayanan yang disediakan oleh pemerintah daerah untuk tujuan kepentingan umum yang dapat dinikmati oleh orang pribadi maupun badan. Jenis dari Retribusi Jasa Umum adalah:

a. Retribusi pelayanan kesehatan

b. Retribusi pelayanan persampahan /kebersihan

c. Retribusi penggantian biaya cetak KTP dan Akta Catatan Sipil

d. Retribusi pelayanan pemakanan dan pengabuan mayat

e. Retribusi parkir tepi jalan umum

f. Retribusi pelayanan pasar

g. Retribusi pengujian kendaraan bermotor

h. Retribusi pemerikasaan alat pemadam kebakaran

i. Retribusi penggantian cetak peta

j. Retribusi penyediaan dan/atau penyedotan kakus

k. Retribusi pengelolaan limbah cair 
1. Retribusi pelayanan tera ulang

m. Retribusi pelayanan pendidikan

n. Retribusi pengendalian menara telekomonikasi

2. Objek Retribusi Jasa Usaha adalah pelayanan yang disediakan oleh Pemerintah Daerah dengan menganut prinsip komersial yang meliputi : (a) pelayanan

menggunakan/ memanfaatkan kekayaan Daerah yang belum dimanfaatkan secara optimal, dan/atau (b) pelayanan oleh Pemerintah Daerah sepanjang belum disediakan secara memadai oleh pihak swasta. Jenis dari Retribusi Jasa Umum adalah:

a. Retribusi pemakaian kekayaan daerah

b. Retribusi pasar grosir dan/atau pertokoan

c. Retribusi tempat pelelangan

d. Retribusi terminal

e. Retribusi tempat parkir khusus

f. Retribusi tempat penginapan/ pensanggrahan/vila

g. Retribusi rumah potong hewan

h. Retribusi pelayanan kepelabuhan

i. Retribusi tempat rekreasi dan olahraga

j. Retribusi penyebrangan air

k. Retribusi penjualan produsi usaha daerah

3. Objek retribusi Perizinan tertentu adlah pelatyanan perizinan tertentu oleh Pemerintah daerah kepada oarang pribadi atau badan yang dimaksud untuk pengaturan dan pengawasan atas kegiatan pemanfaatan ruang, penggunaan sumber daya alam, barang, prasarana, sarana atau fasilitas tertentu guna melindungi kepentingan umum dan menjaga kelestarian lingkungan. Jenis Retribusi perizinan tertentu adalah:

a. Retribusi Izin Mendirikan Bangunan

b. Retribusi Izin tempat menjual minuman beralkohol c. Retribusi izin gangguan

d. Retribusi izin trayek

e. Retribusi izin usaha perikanan

\section{Izin Mendirikan Banguan (IMB)}

Menurut Peraturan Daerah Kabupaten Klaten Nomor 20 Tahun 2011 tentang Retribusi Perizinan tertentu izin Mendirikan Bangunan (IMB) adalah perizinan yang diberikan oleh Pemerinta Daerah kepada pemilik bangunan gedung dan/atau bangunan prasarana yang berdiri sendiri untunk membangun bangunan baru, mengubah, memperluas, mengurangi dan/atau merawat bangunan gedung dan atau bangunan prasarana yang berdiri sendiri sesuai dengan persyaratan administratif dan persyaratan teknis yang berlaku. Pemberian izin mendirikan bangunan meliputi mulai dari peninjauan desain dan pemantauan dari pelaksaan pembangunan agar sesuai dengan rencana teknis dan rencana tata ruang dengan tetap memperhatikan Koefisien Dasar Bangunan (KDB), Koefisien Luas Bangunan (KLB) dan Koefisien Ketinggian Bangunan (KKB) serta pengawasan penggunaan bangunan yang meliputi pemeriksaan dalam rangka memenuhi syarat keselamatan bagi yang menempati bangunan tersebut.

Tingkat penggunaan jasa retribusi IMB diukur berdasarkan:

1. Retribusi IMB Bangunan Gedung = Luas Lantai Bangunan x Koefisien Fungsi Banguanan $\mathrm{x}$ Koefisien Waktu Pemanfaatan Bangunan $\mathrm{x}$ Harga Satuan Retribusi Bangunan Gedung

Harga satuan retribusi gedung di kabupaten klaten adalah Rp. 25.000

2. Retribusi IMB Bangunan Prasarana = Luas/Volume/panjang Bangunan $\mathrm{x}$ Koefisien Bangunan $\mathrm{x}$ Harga Satuan Retribusi Bangunan Prasarana 
Yang menjadi pengecualian objek retribusi IMB adalah untuk bangunan milik Pemerintah atau Pemerintah Daerah. Subjek Retribusi IMB adalah oarang pribadi atau badan yeng menggunakan/menikmati Izin Mendirikan Bangunan. Sedangkan wajib retribusi adlah orang pribadi atau badan yang menggunakan/menikmati izin mendirikan bangunan dan wajib ungtuk melakukan pembayaran retribusi termasuk pemungut atau pemmotong retribusi IMB. Syarat yang diperlukan untuk pengajuan IMB di Kabupaten Klaten adalah sebagai berikut:

1. Fotocopy KTP

2. Fotocopy sertifikat, apabila milik orang lain surat Keterangan pemilik yang bermetarai dan diketahui oleh Kepala Desa

3. Surat keterangan status penggunaan lahan

4. Pelunasan PBB terakhir

5. Surat Pernyataan Pengelolaan Lingkungan oleh BLH bagi bangunan untuk bangunan usaha

6. Dokumen/kajian Andalalin bagi usaha yang diwajibkan memiliki Andalalin

7. Gambaran konstruksi dan perhitungan konstruksi bangunan bertingkat atau yang diperlukan

\section{Potensi Penerimaan}

Potensi merupakan kemampuan yang mempunyai kemungkinan untuk dikembangkan; kekuatan; kesanggupan; daya pengertian potensi ini menurut Kamus Besar bahasa Indonesia. Potensi disini mempunyai makna sesuatu yg teropendam dan belum dimunculkan. Untuk memunculkan potensi yang terpendam diperlukan upaya untuk bisa mewujudkan potensi itu menjadi hasil nyata. Dalam Kamus Besar bahasa indonesia kata Penerimaan bisa diartikan sebagai besarnya uang yang diterima dari hasil penjualan barang atau jasa. Jadi dengan demikian potensi penerimaan bisa diartikan sebagai sesuatu yang dapat dikembangkan atau dimunculkan untuk menghasilkan uang dari penjualan barang atau jasa yang lebih besar. (Soehardi et al., 2020)

\section{Kerangka Penelitian}

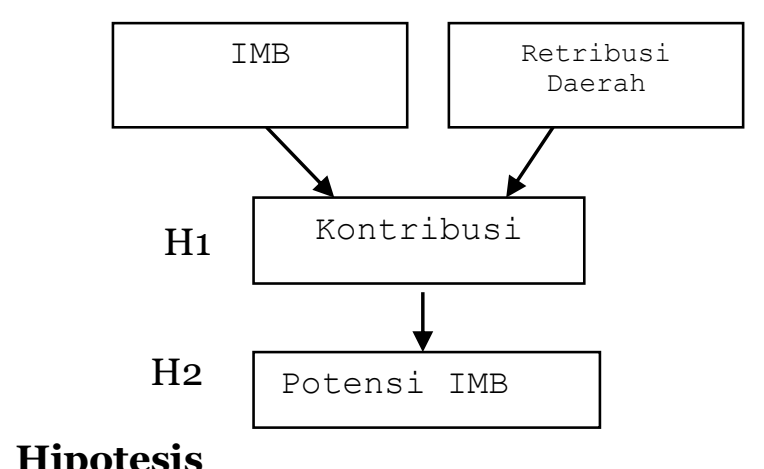

H1: Kontribusi IMB Terhadap Retribusi Daerah termasuk tinggi;

H2: Terdapat peningkatan Potensi Pertumbuhan Penerimaan Retribusi IMB

\section{METODE PENELITIAN}

Dalam penelitian tentang Potensi Penerimaan retribusi Izin Mendirikan Bangunan (IMB) di kabupaten Klaten ini menggunakan Deskriptif Kualitatif. Teknik pengumpulan data menggunakan dokumentasi yang berupa dokumen Anggaran dan Realisasi Pendapatan daerah Kabupaten Klaten Tahun 2014-2019. Fokus dari penelitian ini adalah:

1. Kontribusi Retribusi IMB terhadap retribusi Daerah

2. Potensi Penerimaan Retribusi IMB Kabupaten Klaten tahun 2020-2022

Analisis Data yang digunakan dalam penelitian ini adalah:

1. Kontribusi Retribusi IMB terhadap Retribusi Daerah 
Rumus menghitung kontribusi adalah:

$P n=(Q X n / Q Y n) \times 100 \%$
Sumber:Halim (2004)

Keterangan:

Pn : Kontribusi penerimaan PAD terhadap

Pendapatan Daerah

QY : Realisasi Pendapatan Daerah

QX : Realisasi PAD

$\mathrm{N}$ : Tahun (periode tertentu)

Tabel 1. Kriteria Kontribusi PAD.

\begin{tabular}{|l|l|}
\hline $\begin{array}{c}\text { Persentase kontribusi } \\
\text { retribusi daerah }\end{array}$ & \multicolumn{1}{|c|}{ Kriteria } \\
\hline$\geq 50$ & Sangat Baik \\
\hline $40-50$ & Baik \\
\hline $30-40$ & Sedang \\
\hline $20-30$ & Cukup \\
\hline $10-20$ & Kurang \\
\hline$\leq 10$ & Sangat Kurang \\
\hline
\end{tabular}

Sumber : Halim (2004)

2. Menghitung dan menyusun tabel analisis Potensi Penerimaan Retribusi IMB Kabupaten Klaten tahun 20202022 menggunakan metode least square method (metode kuadrat terkecil).

Bentuk persamaan yang digunakan sebagai berikut:

$\mathrm{Y}=\mathrm{a}+\mathrm{bX}$

Sumber : Sudjana 1996:315

Keterangan:

$\mathrm{Y}=$ Variabel yang diramalkan

$\mathrm{a}=$ Bilangan Konstan $(\mathrm{a}=\Sigma \mathrm{Y} / \mathrm{N})$

$\mathrm{b}=$ Koefisien arah regresi linier $(\mathrm{b}=\Sigma \mathrm{XY} /$ $\Sigma \mathrm{X}^{2}$ )

$\mathrm{X}=$ Variabel waktu (tahun)

\section{HASIL PENELITIAN PEMBAHASAN}

Retribusi daerah menjadi salah satu sumber dari Pendapatan Asli Daerah.
Pendapatan Asli Daerah merupakan salah satu tolok ukur kemandirian seuatu Pemerintah Daerah. PAD itu sendiri yang sangat mungkin dilakukan pembenahan dan perbaikan oleh Pemerintah Daerah itu sendiri. Dalam UU No 34 Tahun 2000 Pasal 18 menetukan bahwa yang menjadi objek dari retribusi adalah jenis jasa tertentu yang disediakan oleh Pemerintah Daerah. Tidak semua jasa yang diberikan akan dipungut retribusi hanya jasa tertentu yang mempunya sosial ekonomi tertentu. Retribusi Izin Mendirikan Bangunan (IMB) menjadi salah satu retribusi perizinan tertentu yang di pungut di kabupaten Klaten. Retribusi IMB membil bagian dalam jumlah retribusi Daerah secara keseluruhan yang berguna untuk pembelanjaan daerah.

Tabel 2. Realisasi Penerimaan Retribusi Daerah Kabupaten Klaten Periode 2014-2019

\begin{tabular}{|c|c|}
\hline Tahun & Jumlah \\
\hline 2014 & 21.220 .132 .236 \\
\hline 2015 & 21.894 .721 .448 \\
\hline 2016 & 22.559 .038 .217 \\
\hline 2017 & 22.559 .038 .217 \\
\hline 2018 & 13.030 .982 .654 \\
\hline 2019 & 17.296 .912 .453 \\
\hline
\end{tabular}

Sumber : Badan Pengelola Keuangan Kab Klaten

Tabel 3. Realisasi Penerimaan Retribusi IMB Periode 2014-2019

\begin{tabular}{|c|c|}
\hline Tahun & Jumlah \\
\hline 2014 & 1.801 .262 .259 \\
\hline 2015 & 3.415 .565 .549 \\
\hline 2016 & 3.156 .636 .692 \\
\hline 2017 & 2.061 .753 .643 \\
\hline 2018 & 1.660 .014 .482 \\
\hline 2019 & 3.193 .438 .238 \\
\hline
\end{tabular}

Sumber : Badan Pengelola Keuangan Kab Klaten

1. Kontribusi IMB Terhadap Penerimaan Retribusi Daerah

IMB merupakan bagian dari Retribusi Daerah jenis Perizinan Tertentu. Dalama bagian ini akan dilihat dianalisa seberapa besarnya kontribusi dari IMB ini 
terhadap penerimaan Retribusi Daerah secara keseluruhan.

Tabel 4. Kontribusi IMB Terhadap Retribusi Daerah Kabupaten Klaten Periode 2014-2019

\begin{tabular}{|c|c|c|c|c|}
\hline Tahun & Retribusi Daerah & IMB & Kontribusi & Kategori \\
\hline 2014 & 21.220 .132 .236 & 1.801 .262 .259 & $8,49 \%$ & $\begin{array}{c}\text { Sangat } \\
\text { Kurang }\end{array}$ \\
\hline 2015 & 21.894 .721 .448 & 3.415 .565 .549 & $15,60 \%$ & Kurang \\
\hline 2016 & 22.559 .038 .217 & 3.156 .636 .692 & $13,99 \%$ & Kurang \\
\hline 2017 & 22.559 .038 .217 & 2.061 .753 .643 & $9,14 \%$ & $\begin{array}{c}\text { Sangat } \\
\text { Kurang }\end{array}$ \\
\hline 2018 & 13.030 .982 .654 & 1.660 .014 .482 & $12,74 \%$ & Kurang \\
\hline 2019 & 17.296 .912 .453 & 3.193 .438 .238 & $18,46 \%$ & Kurang \\
\hline
\end{tabular}

Sumber: Badan Pengelola Keuangan Kab Klaten

Gambar 5. Kontribusi IMB Terhadap Retribusi Daerah Periode 2014-2019

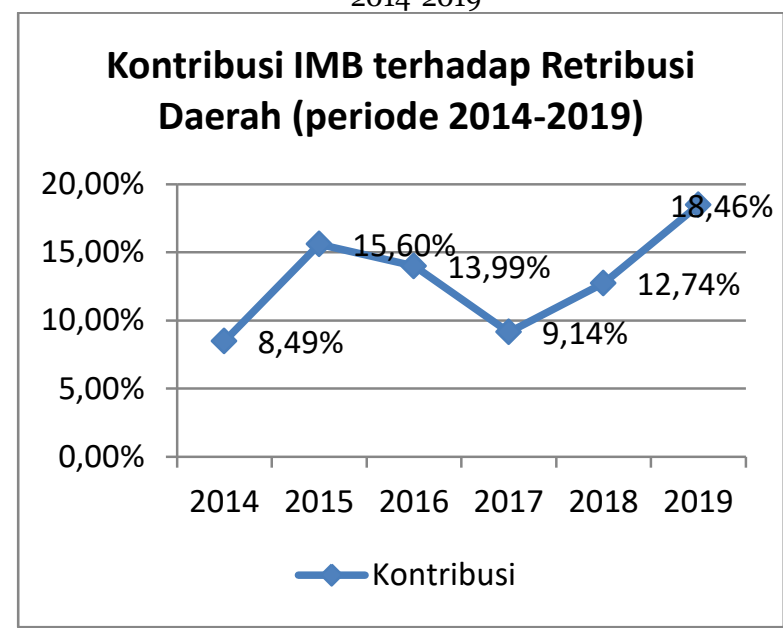

Sumber: Badan Pengelola Keuangan Kab Klaten

Kontribusi dari Retribusi IMB terhadap Penerimaan retribusi Daerah secara keseluruhan masuk kategori kurang dan sangat kurang. Prosentase kontribusi fluktuatif naik di tahun 2015 kemudian mulai tirun di tahun 2016 dan 2017,perlahan mulai naik pada tahun 2018 dan 2019 yang merupakan prosentase kontribusi tertinggi sebesar 16,46 \%. Melihat dari kontribusi yang masih kurang dan sangat kurang ini mengindikasikan bahwa masih banyak bangunan yang belum mempunyai IMB yang seharusnya menjadi persyaratan dalam mendirikan bangunan agar sesuai dengan rencana tata ruaang Kabupaten Klaten.

2. Potensi Penerimaan ratribusi IMB tahun 2020-2022

Potensi penerimaan retribusi IMB untuk tahun 2020-2022 di hitung menggunakan metode least square (kuadrat terkecil) metode ini umum digunakan untuk membuat persamaan tren dan untuk meramalkan periode berikutnya. Untuk membuat peramalan potensi retribusi IMB tahun 2020-2022 perlu dibuat tabel untuk membuat persamaan sebagai berikut:

Tabel 6. Analisis potensi penerimaan Retribusi IMB dengan

\begin{tabular}{|c|c|c|c|c|}
\hline \multicolumn{5}{c}{ metode least square: } \\
\hline Tahun & IMB (Y) & X & $X^{2}$ & XY \\
\hline 2014 & 1.801 .262 .259 & -5 & 25 & $(9.006 .311 .295)$ \\
\hline 2015 & 3.415 .565 .549 & -3 & 9 & $(10.246 .696 .647)$ \\
\hline 2016 & 3.156 .636 .692 & -1 & 1 & $(3.156 .636 .692)$ \\
\hline 2017 & 2.061 .753 .643 & 1 & 1 & 2.061 .753 .643 \\
\hline 2018 & 1.660 .014 .482 & 3 & 9 & 4.980 .043 .446 \\
\hline 2019 & 3.193 .438 .238 & 5 & 25 & 15.967 .191 .190 \\
\hline $\begin{array}{l}\text { Jumlah } \\
=6\end{array}$ & 15.288 .670 .863 & 0 & 70 & 599.343 .645 \\
\hline
\end{tabular}

Sumber: Badan Pengelola Keuangan Kab Klaten

Bentuk persamaan yang digunakan sebagai berikut:

$\mathrm{Y}=\mathrm{a}+\mathrm{bX}$

Sumber : Sudjana 1996

Keterangan:

$\mathrm{Y}=$ Variabel yang diramalkan

$\mathrm{a}=$ Bilangan Konstan $(\mathrm{a}=\Sigma \mathrm{Y} / \mathrm{N})$

$\mathrm{b}=$ Koefisien arah regresi linier $(\mathrm{b}=\Sigma \mathrm{XY} /$

$\left.\Sigma \mathrm{X}^{2}\right)$

$\mathrm{X}=$ Variabel waktu (tahun)

Pertama yang harus dicari variabel a dan b menggunakan persamaan sebagai berikut:

1. $\mathrm{a}=\Sigma \mathrm{Y} / \mathrm{N}$ 


$$
\begin{aligned}
& a=15.288 .670 .863 / 6 \\
& a=2.548 .111 .811
\end{aligned}
$$

2. $\mathrm{b}=\Sigma \mathrm{XY} / \Sigma \mathrm{X}^{2}$

$$
\begin{aligned}
& b=599.343 .645 / 70 \\
& b=8.562 .052
\end{aligned}
$$

setelah variabel a dan $b$ dapat dibuat persamaan sebagai berikut

$\mathrm{Y}=2.548 .111 .811+8.562 .052 \mathrm{X}$

Tabel 7. titik tengah untuk analisis potensi penerimaan IMB

\begin{tabular}{|c|c|}
\hline Tahun & $\mathrm{X}$ \\
\hline 2020 & 7 \\
\hline 2021 & 9 \\
\hline 2022 & 11 \\
\hline
\end{tabular}

Dari nilai $\mathrm{X}$ tersebut dimasukan ke dalam persamaan $\mathrm{Y}=\mathbf{2} .548 .111 .811+8.562 .052 \mathrm{X}$

Tabel 8. Potensi Penerimaam Retribusi IMB Tahun 2020-2022

\begin{tabular}{|c|c|c|}
\hline Tahun & X & Potensi \\
\hline 2020 & 7 & 2.608 .046 .175 \\
\hline 2021 & 9 & 2.625 .170 .279 \\
\hline 2022 & 11 & 2.642 .294 .383 \\
\hline
\end{tabular}

Sumber: Badan Pengelola Keuangan Kab Klaten

Tabel 4.7. Retribusi IMB dan Potensi Penerimaan retribusi IMB

\begin{tabular}{|c|c|}
\hline Tahun & IMB \\
\hline 2014 & 1.801 .262 .259 \\
\hline 2015 & 3.415 .565 .549 \\
\hline 2016 & 3.156 .636 .692 \\
\hline 2017 & 2.061 .753 .643 \\
\hline 2018 & 1.660 .014 .482 \\
\hline 2019 & 3.193 .438 .238 \\
\hline 2020 & 2.608 .046 .175 \\
\hline 2021 & 2.625 .170 .279 \\
\hline 2022 & 2.642 .294 .383 \\
\hline
\end{tabular}

Sumber: Badan Pengelola Keuangan Kab Klaten

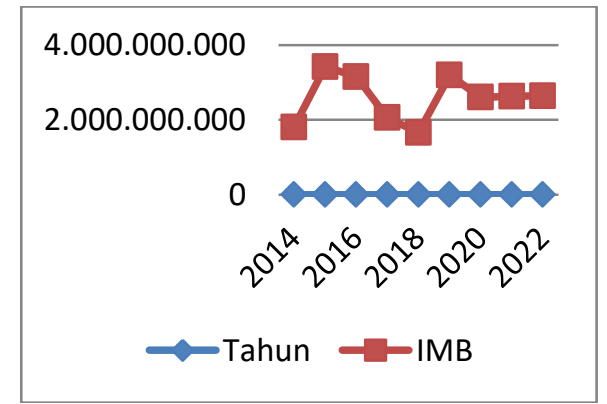

Gambar 2. Retribusi IMB dan Potensi Penerimaan retribusi IMB
Dalam grafik tren potensi penerimaan IMB menurun ini disebabkan metode peramalan least square menganalisis trend tahunun 2014-2019 yang sangat fluktuatif yang rendah pada tahun 2014 kemudian naik tahun 2015, tahun 2016-2018 terus menurun kemudian baru naik lagi di tahun 2019. Naik turunnya dan peningkatan potensi penerimaan IMB yang sedikit ini disebabkan banyak bangaunan di kabupaten Klaten yang belum mengurus perizinan IMB. Kabupaten Klaten secara budaya tempat tinggal adalah model pedesaan yang lebih banyak. Pedesaan dengan bangunan rumah yang sudah ada untuk turun temurun dan banyak bangunan di desa yang memang tidak dilengkapi dengan IMB, beda dengan perumahan modern yang biasanya dari pengembang sudah melakukan perizinan IMB. Jadi ini yang menyebabkan kontribusi dan potensi penerimaan yang kurang.

\section{KESIMPULAN}

1. Tingkat Kontribusi Retribusi IMB terhadap Retribusi daerah kabupaten Klaten dalam kategori kurang dan sangat kurang.

2. Potensi Penerimaan retribusi IMB peramalan tahun 2020-2022 justru mengalami penurunan di 2020 dan meningkat perlahan di tahun 2021 dan 2022

\section{Saran}

1. Melakukan sosialisasi tentang IMB sampai ke desa-desa sehingga masyarakat paham dan sadar akan kewajiban pengurusan IMB.

2. Melakukan pemutihan atau pengurangan biaya pengurusan IMB terhadap bangunan terutama rumah tinggal yang di pedesaan yang sudah 
ada dengan tetap memperhatikan Peraturan Daerah dan Rencana Tata Ruang Daerah.

3. Melakukan pemetaan dan menbuat database tentang objek retribusi IMB secara menyeluruh dan dinamis.

4. Setelah melakukan pemetaan maka dibuat target penerimaan Retribusi sesuai dengan hasil pemetaan tersebut.

5. Meningkatkan penegakan Hukum terhadap pelanggaran dalam Peraturan Daerah retribusi IMB.

\section{Daftar Pustaka}

Djanggih, H., \& Ahmad, K. (2020). Implementasi Penarikan Retribusi Izin Mendirikan Bangunan Terhadap Realisasi Pendapatan Asli Daerah . Jurnal Kertha Patrika, 42(1), 76-86.

Halim, Abdul. 2004. Manajemen Keuangan Daerah. Edisi Revisi. Yogyakarta:UPP AMP YKPN.

Mardiasmo. 2009. Otonomi dan Manajemen Keuangan Daerah. Yogyakarta:Andi Offset.

Mardiasmo, 2016. Perpajakan Edisi Terbaru 2016. Yogyakarta: Penerbit ANDI.

Marihot.2016. Pajak Daerah dan Retribusi Daerah.Jakarta: Rajawali Pers.

Pemerintah Indonesia. 2004. UndangUndang No 32 tahun 2004 Tentang Pemerintah Daerah. Lembaran RI tahun 2004 No 32. Jakarta:Sekretariat Negara.

Pemerintah Indonesia. 2009. UndangUndang No 28 tahun 2009 Tentang Pajak Daerah dan Retribusi Daerah. Lembaran RI tahun 2009 No 28. Jakarta:Sekretariat Negara.

Pemerintah Kabupaten Klaten . 2011. Peraturan Daerah Kabupaten Klaten No 20 Tahun 2011 Tentang Retribusi Perizinan Tertentu.

Pemerintah Kabupaten Klaten . 2011. Peraturan Daerah Kabupaten Klaten
No 11 Tahun 2011 Tentang Rencana

Tata Ruang Wilayah Kabupaten Klaten Tahun 2011-2031.

Pemerintah Kabupaten Klaten . 2015. Peraturan Daerah Kabupaten Klaten No 5 Tahun 2015 Tentang Izin Pemanfaatan Ruang.

Soehardi, S., Permatasari, D. A., \& Sihite, J. (2020). Pengaruh Pandemik Covid-19 Terhadap Pendapatan Tempat Wisata dan Kinerja Karyawan Pariwisata di Jakarta. Jurnal Kajian Ilmiah, 1(1), 114.

https://doi.org/https://doi.org/10.315 99/jki.v1i1.216

Sudjana. 1996. Teknik Analisis Regresi dan Korelasi. Bandung: Tarsito.

Widyatmoko (2013). Studi Potensi

Retribusi Ijin Mendirikan Bangunan (IMB) Dalam rangka Optimalisasi pendapatan Asli Daerah Kabupaten Sleman. JBMA 1(2), 6281.7/0047287514535847 